\title{
PENGEMBANGAN DAN PENINGKATAN KINERJA PAMONG BELAJAR SANGGAR KEGIATAN BELAJAR
}

\author{
Melati Indri Hapsari*
}

\begin{abstract}
The success of a Learning Activity Center much depends on the tutors' competence and creativity. This articles discusses some variables influencing the tutors' performance and puts forward a number of suggestions to improve the tutors' performance.
\end{abstract}

Keywords: performance, tutor, Learning Activity Centre.

\section{PENDAHULUAN}

Ada banyak program pendidikan nonformal dan informal yang sekarang ini diselenggarakan baik oleh PKBM, LSM, SKB dan lembaga-lembaga lainnya. Program- program tersebut secara garis besar dapat dikelompokkan dalam program pendidikan anak usia dini, life skills, kesetaraan, keaksaraan, dan gender. Dari masing-masing kelompok program tersebut banyak terdapat program-program seperti dalam program kesetaraan ada program Kejar Paket A, Paket B, dan Paket $C$ serta memungkinkan akan muncul program lebih lanjut melalui program inovasi lainnya. Pada program PAUD terdapat program Kelompok Bermain, Tempat Penitipan Anak dan Tempat Pendidikan Al-Quran serta program lain yang mendukung program PAUD.

Kegiatan-kegiatan tersebut di atas perlu dikembangkan untuk meningkatkan kualitas pendidikan nonformal dan informal. Pamong Belajar sesuai dengan tugas pokoknya mempunyai fungsi mengembangakan model-model pembelajaran pendidikan nonformal dan informal. Oleh karena itu, kompetensi pamong belajar harus bisa memenuhi tuntutan tersebut.

Pamong belajar SKB pada umumnya lebih mengedepankan pada tugas pokok dan fungsi lembaganya. Menurut SK Mendikbud No. 023/O/1997 tugas Sanggar Kegiatan Belajar (SKB) adalah melakukan pembuatan percontohan dan pengendalian mutu program pendidikan nonformal dan informal. Adapun fungsinya adalah (1) pembangkitan dan penumbuhan kemauan belajar masyarakat dalam rangka terciptanya masyarakat gemar belajar; (2)

*Pamong Belajar P2PNFI Regional II Semarang pemberian motivasi dan pembinaan masyarakat agar mau dan mampu menjadi pendidik dalam melaksanakan asas saling membelajarkan; (3) pemberian pelayanan informasi kegiatan pendidikan nonformal dan informal; (4) pembuatan percontohan berbagai program dan pengendalian mutu pelaksanaan program pendidikan nonformal dan informal; (5) penyu sunan dan pengadaan sarana muatan lokal; (6) penyediaan sarana dan fasilitas belajar; (7) pengintegrasian dan pensinkronisasian kegiatan sektoral dalam bidang pendidikan nonformal dan informal; (8) pelaksanaan pendidikan dan pelatihan tenaga pelaksana pendidikan nonformal dan informal; 9) pengelolaan urusan tata usaha sanggar.

Sebagaimana tugas lembaganya, pamong belajar SKB dituntut untuk bisa menyelenggarakan program pendidikan nonformal dan informal yang secara kualitas mampu menjadi panutan bagi lembaga penyelenggara pendidikan nonformal dan informal lain seperti PKBM dan LSM penyelenggara program pendidikan nonformal. Hasil evalusi penyelenggaraan pelayanan program pendidikan nonformal dan informal di SKB menunjukkan bahwa program-program yang diselenggarakan belum memenuhi persyaratan mutu, kurang inovatif dalam penyelengaraan program sehingga program yang seharusnya menjadi percontohan masih jauh dari yang diharapkan.Hal tersebut tidak lepas dari rendahnya kompetensi pamong belajar sebagai ujung tombak pelaksana program pendidikan nonformal dan informal di SKB, keterbatasan sarana dan prasarana yang digunakan oleh pamong belajar SKB, akses pamong belajar yang minim, kemimpinan, dan manajemen kepala yang rendah. 
Berkaitan dengan upaya pemerintah agar SKB sebagai unit pelaksana teknis pendidikan nonformal dan informal yang bertugas membuat percontohan dan pengendalian mutu maka pamong belajar menjadi kunci utama untuk melaksanakan tugas-tugas SKB dalam mewujudkan berbagai program pendidikan nonformal dan informal yang bermutu, inovatif, dan layak dicontoh oleh masyarakat. Oleh karena itu, perlu adanya upaya untuk meningkatan kinerja pamong belajar SKB agar ke depan program-program SKB lebih unggul dari segi kualitas sehingga bisa menjadi panutan bagi lembaga lain yang menyelenggarakan program pendidikan nonformal yang sama (Tim Pengembang, 2004).

\section{PEMBAHASAN}

Pamong belajar adalah pegawai negeri sipil yang diberi tugas, tanggung jawab, wewenang, dan hak secara penuh oleh pejabat yang berwenang untuk melaksanakan kegiatan belajar mengajar dalam rangka pengembangan model dan pembuatan percontohan serta penilaian dalam rangka pengendalian mutu dan dampak pelaksanaan program pendidikan luar sekolah dan pemuda serta olahraga (Kepmenkowasbangpan NO. 25/KEP/MK.WASPAN/G/6/1999; pasal 1 ayat 1. Dalam ketentuan umum, pamong belajar dibedakan menjadi dua, yaitu pamong belajar terampil dan ahli.

Tugas pokok pamong belajar secara umum terdiri atas: (1) melaksanakan pengembangan model program pendidikan nonformal dan informal, (2) melaksanakan kegiatan belajar mengajar dalam rangka pengembangan model dan pembuatan program PNFI, serta (3) melaksanakan penilaian dalam rangka pengendalian mutu dan dampak pelaksanaan program PNFI.

Selanjutnya berdasarkan jabatannya sesuai dengan (Kepmenkowasbangpan No. 25/KEP/ MK.WASPAN/G/6/1999, pamong belajar diperinci lagi. Berdasarkan tugas pokok tersebut, dapat diambil kesimpulan bahwa peran pamong belajar adalah sebagai berikut (Wijatmoko, 2004).

Agen Pembelajaran

Pamong belajar berperan sebagai agen pembelajaran berarti pamong belajar sebagai narasumber belajar bagi mereka yang membutuhkan, yaitu warga belajar. Sebagai agen pembelajaran pamong belajar harus mempunyai empat kompetensi dasar (PP No 19 tahun 2005) sebagai berikut. Pertama, kompetensi pedagogi dan andragogi, kompetensi pedagodi terkait dari latar belakang pendidikan yang sudah ditempuh oleh seorang pamong belajar baik itu S1, S2 ataupun S3 yang sesuai atau membekali pamong belajar dalam melaksanakan tugasnya sebagai seorang pamong sedangkan kompetensi andargogi terkait dengan bagaimana seorang pamong belajar dengan kemampuan, bakat, pengenalan potensi diri dan lingkungan, serta pengalaman yang dia miliki mampu untuk mengembangkan dirinya untuk melaksanakan tugas dan kemampuannya dalam menjawab perkembangan zaman.

Kedua, kompetensi personal (kepribadian) adalah dasar pengembangan sikap kepribadian dalam menyikapi fenomena dan problematika yang ada pada lingkungan internal maupun eksternal (pribadi dan lingkungannya). Ketiga, kompetensi profesional dengan bagaimana seorang pamong menjalankan tugas dan fungsi sebagai pamong belajar, yaitu sebagai pelaksana dalam pengembangan model, pelaksana kegiatan belajar mengajar dalam rangka pengembangan model, dan pembuatan percontohan serta pelaksana pengendali mutu dan dampak pelaksanaan program pendidikan nonformal dan informal.

Keempat, kompetensi sosial meliputi kesadaran diri (minat, bakat, sikap, dan kecakapan), percaya diri, komunikasi dengan orang lain, tenggang rasa dan kepedulian pada sesama, hubungan antarpersonal, pemahaman dan pemecahan masalah, menemukan dan mengembangkan kebiasaan positif, serta kemandirian dan kepemimpinan. Kelima, difusi inovasi. Inovasi adalah gagasan baru, tindakan atau barang yang dianggap baru oleh seseorang atau satuan pengguna lain. Difusi adalah proses disebarkan 'produk' kepada anggota dari suatu sistem sosial. Sehingga difusi inovasi dapat diartikan sebagai penyebaran informasi kepada seseorang atau masyarakat terhadap inovasi yang ditemukan agar orang atau masyarakat tersebut mengetahui dan membuat sebuah perubahan dari informasi yang disampaikan.

Keenam, change agent (agen pembaharu). Sebagai agen pembaharu pamong belajar memiliki empat peran utama, yaitu: (1) the change agent as catalyst (agen pembaharu sebagai katalisator), yaitu menggerakkan masyarakat untuk melakukan perubahan; (2) the change agent as solution giver (agen pembaharu sebagai pemberi pemecahan persoalan) yaitu menyediakan alternatif-alternatif pemecahan permasalahan dan menghubungkan berbagai alternatif tersebut dengan kebutuhan klien; (3) the change agent as process helper (agen pembaharu sebagai pembantu 
proses perubahan) membantu dalam proses masalah dan penyebaran informasi, serta memberi petunjuk mengenai bagaimana mengenali merumuskan kebutuhan, mendiagnosa permasalahan dan menentukan tujuan, mendapatkan sumber-sumber yang relevan, memilih atau menciptakan pemecahan masalah, menyesuaikan dan merencanakan pentahapan pemecahan masalah; serta (4) the change agent as source linker (agen pembaharu sebagai penghubung), yaitu penghubung dengan sumbersumber yang diperlukan untuk pemecahan masalah yang dihadapi.

Pengertian kinerja atau produktivitas kerja atau hasil kerja menurut Kamus Besar Bahasa Indonesia adalah kemampuan untuk menghasilkan sesuatu. Jadi kinerja atau produktivitas adalah hasil kerja, pelaksanaan kerja dan keluaran yang dihasilkan dari suatu proses pekerjaan. Kata kinerja merujuk pada hasil dan penyelesaian tugas, penanganan atau pelaksanaan suatu pekerjaan (Robbin, 2001). Dalam kerangka organisasi, kinerja merupakan hasil evaluasi terhadap pekerjaan yang dilakukan dibandingkan dengan kriteria yang telah ditetapkan. Kinerja prestasi kerja dan kinerja dipengaruhi oleh usaha tetapi pada gilirannya prestasi kerja mempengaruhi kepuasan dan ganjaran. Kinerja seseorang kaitannya dengan penilaian terhadap hasil kerjanya sesuai standar kinerja karena standar kinerja merupakan tolok ukur antara apa yang telah dilakukan. Dengan apa yang diharapkan sesuai dengan pekerjaan, jabatan dan tanggung jawab (Nainggolan, 2006).

Dari uraian di atas dapat disimpulkan yang dimaksud dengan kinerja adalah cara, usaha, dan hasil kerja yang dapat dicapai seseorang atau sekelompok orang dalam suatu organisasi, sesuai dengan wewenang dan tanggung jawab masing-masing dalam upaya mencapai tujuan organisasi yang bersangkutan. Kinerja pamong belajar adalah kemampuan pamong belajar dengan dorongan motivasi dan kesempatan dalam melaksanakan tugas dan fungsinya dalam mencapai tujuan yang diinginkan.

\section{Variabel yang Berpengaruh dalam Kerja}

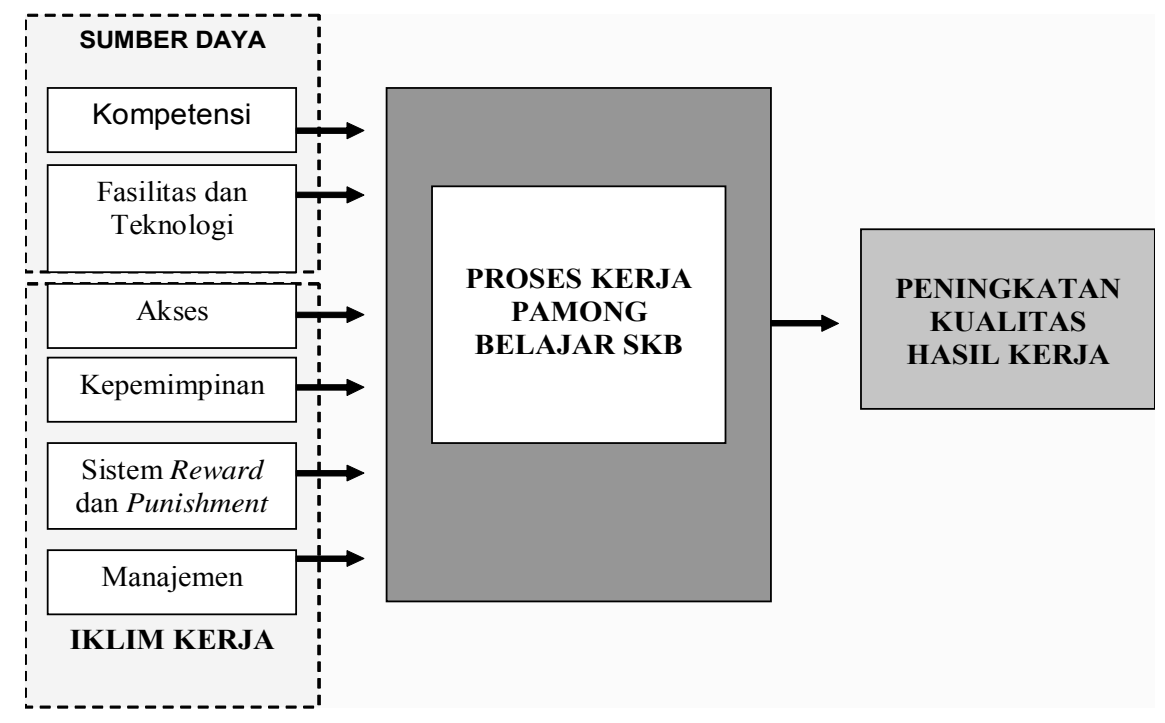

Gambar 1. Variabel yang berpengaruh dalam kerja

Dari bagan yang berpengaruh terhadap proses kerja Pamong Belajar SKB di atas dapat digambarkan ada dua variabel yang mempengaruhi kinerja pamong belajar, yaitu sumber daya dan iklim kerja (Wartanto, 2005).

\section{Sumber Daya}

Kompetensi

\section{Pengembangan Profesi}

Kompetensi pengembangan profesi berhubungan erat dengan bagaimana pamong belajar dapat mengembangkan karier kepamongannya sebagaimana peraturan yang berlaku. Jabatan diberikan berdasarkan volume kerja dan prestasi yang dia lakukan.
Kemampuan pengembangan profesi terutama dalam upaya menemukan berbagai model-model inovatif dan memperluas cakupan program PNFI yang dapat digunakan untuk menunjang pelaksanaan kegiatan kepamongan.

2. Kompetensi akademik

Kompetensi akademis merupakan ciri khas individu yang berpendidikan tinggi, serta cakrawala pandang yang luas tentang lingkungan fisik dan sosial budayanya, lingkungan alamiah dan buatan, termasuk cara-cara mengupayakan pemahaman terhadap gejalagejala alamiah dan sosial budaya. Kemampuan menyatakan pikir secara jelas dan lugas dengan bahasa 
yang mudah dipahami baik secara lisan maupun tulisan, kemampuan menilai proses dan hasil berpikir sendiri disamping proses dan hasil berpikir orang lain serta mengemukakan perbedaan pendapat secara efektif. Kemampuan akademik merupakan dasar pijakan dalam mengkaji, menganalisis dan mengkritisi fenomena yang berkembang dalam pelaksanaan pendidikan (Hastuti, 2004).

3. Kompetensi personal sosial

Kompetensi personal sosial meliputi kesadaran diri (minat, bakat, sikap, dan kecakapan), percaya diri, komunikasi dengan orang lain, tenggang rasa dan kepedulian pada sesama, hubungan antarpersonal, pemahaman dan pemecahan masalah, menemukan dan mengembangkan kebiasaan positif, serta kemandirian dan kepemimpinan. Kemampuan personal adalah dasar pengembangan sikap kepribadian dalam menyikapi fenomena dan problematika yang ada pada lingkungan internal maupun eksternal (pribadi dan lingkungannya) (Hastuti, 2004).

4. Kompetensi budaya

Kompetensi budaya adalah bagaimana pamong belajar memahami nilai-nilai yang berkembang di masyarakat di mana dia berada dan mengembangkannya untuk kepentingan tugas kepamongan, pribadi, dan lembaga. Penguasaan budaya untuk memperkuat pengembangan keanekaragaman budaya lokal dan nasional dalam pemilihan atau pengalokasian berbagai program PNFI sesuai dengan kebutuhan wilayah (Hastuti, 2004).

5. Kompetensi teknis

Kompetensi teknis adalah kompetensi pamong belajar dalam melaksanakan tugas dan fungsinya (job description) sesuai dengan peraturan atau perundangundangan yang berlaku. Pada jenjang kepangkatan tertentu mempunyai tugas dan wewenang sendiri-sendiri (Hastuti, 2004).

Fasilitas dan teknologi

Fasilitas dan teknologi mutlak diperlukan agar proses kerja dapat berjalan dengan baik. Proses kerja dapat berjalan dengan baik jika peralatan dan teknologi yang digunakan sesuai dengan bidang kerja dan standarnya.

\section{Iklim Kerja}

Manajemen

Manajemen dalam arti klasik adalah seni memperoleh hasil melalui berbagai kegiatan yang dilakukan oleh orang lain. Unsur dari kegiatan manajemen adalah adanya manusia sebagai pelaku, adanya sistem yang bersifat mengatur dan mengikat dan adanya tujuan atau target akan dicapai. Dari ketiga unsur tersebut harus bersinergi satu dengan yang lain. Manusia sebagai pelaku harus didukung dengan kemampuan yang cukup untuk mencapai tujuan yang diinginkan. Adapun sistem haruslah bersifat aplikatif, mengikat namun juga fleksibel sehingga memudahkan bagi pelaku untuk mencapai tujuan. Target yang harus dicapai juga harus realistis namun juga jangan terlalu rendah. Pencapaian target bisa dilakukan secara bertahap dalam jangka waktu tertentu dan berkesinambungan.

Kepemimpinan

Tipe kepemimpinan seseorang mempengaruhi proses kerja karena kepemimpinan berkaitan dengan gaya pengambilan keputusan, pemeliharaan hubungan antara atasan dengan para bawahan, pandangan tentang tingkat kematangan atau kedewasaan para bawahan baik dalam arti psikologis maupun teknis, orientasi dalam pemenuhan kebutuhan para bawahan, persepsi tentang pelaksanaan tugas dikaitkan dengan hubungan dengan para bawahan. Adapun faktor-faktor yang perlu diperhatikan oleh seorang pemimpin antara lain kedisiplinan, cara berpakaian, perilaku, tutur kata serta sebagai agen dinamisator lingkungan.

\section{Sistem Reward dan Punishment}

Pemberian penghargaan dan hukuman harus dilaksanakan untuk mendukung proses kerja agar berjalan optimal. Reward diberikan jika: (1) pamong belajar mencetak prestasi yang berpengaruh terhadap kemajuan SKB; (2) pamong belajar melaksanakan tugas dan kewajiban sesuai dengan job description masing-masing; (3) pamong belajar mampu menemukan penemuan-penemuan baru yang bermanfaat bagi tugas kepamongannya, SKB, dan warga masyarakat; serta (4) pamong belajar berdedikasi dan mempunyai disiplin tinggi.

Punishment dikenakan jika: (1) pamong belajar melalaikan tugas dan kewajibannya; (2) pamong belajar melakukan pelanggaran terhadap tata tertib lembaga SKB; (3) pamong belajar melakukan pelanggaran terhadap norma agama, sosial, dan hukum uang dapat merusak reputasi pamong belajar sendiri maupun SKB; serta (4) akses dapat diartikan sebagai pemberian kemudahan jalan bagi pamong belajar untuk mengembangkan minat, bakat, kemampuan, visi, dan misinya terhadap tugas serta kewajibannya sebagai pamong untuk berperan serta dalam program PNFI. Proses kerja akan menjadi berjalan dengan maksimal jika dua variabel tersebut memenuhi standar minimal kinerja pamong belajar.

Cara Mengembangkan dan Meningkatkan Kinerja 


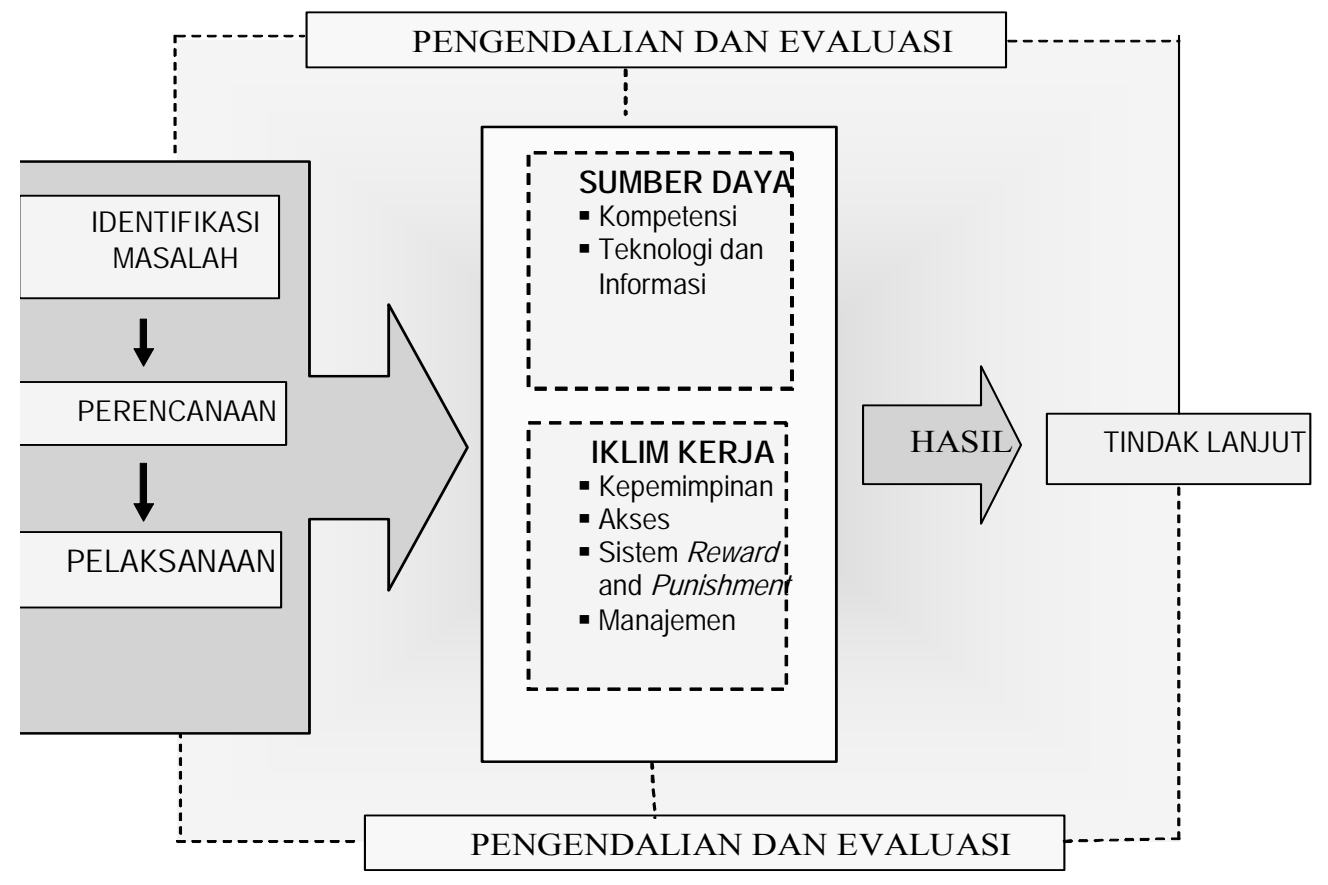

Gambar 2. Cara mengembangan dan meningkatkan kinerja standar operasional prosedur pengembangan dan peningkatan kinerja pamong belajar

Pengembangan dan peningkatan kinerja pamong belajar SKB memerlukan beberapa langkah. Langkahlangkah tersebut digambarkan pada bagan di atas. Pertama, identifikasi masalah. Sebagaimana telah diuraikan di atas ada enam variabel yang mempengaruhi kinerja pamong belajar. Dari enam variabel tersebut dapat dilihat kelemahan-kelemahan yang ada di pada pamong belajar SKB dengan menggunakan instrumen sebagai standar atau melalui pengamatan. Variabel apa yang masih kurang, apakah itu kompetensi, fasilitas, dan teknologi.

Kedua, menyusun rencana. Setelah diketahui bagian yang lemah sehingga menyebabkan kinerja pamong belajar SKB rendah, selanjutnya dapat disusun kegiatan untuk meningkatkan kinerja pamong belajar. Ketiga, pelaksanaan. Beberapa solusi yang bisa dilakukan dalam menyelesaikan masalah tersebut adalah sebagai berikut.

1. Peningkatan kompetensi berhubungan erat dengan kemampuan yang dimiliki pamong dalam melaksanakan tugas dan kewajibannya. Beberapa kegiatan yang bisa dilakukan untuk meningkatkan kompetensi pamong sebagai berikut.

Pertama, pelatihan pamong belajar biasanya tidak dilakukan sendiri oleh SKB karena biaya yang dikeluarkan sangat besar. Biasanya pelatihan diselenggarakan oleh instansi yang cukup besar misalnya BPKB, BPPNFI, P2PNFI dan dinas pendidikan propinsi, sehingga pelibatan pamong belajar SKB sebatas sebagai peserta pelatihan.
Dalam mengirim peserta pelatihan hendaknya dipertimbangkan hal-hal (a) latar belakang kompetensi pamong sesuai dengan tema pelatihan misalnya pelatihan pengelola PAUD, (2) Penilaian Angka Kredit PB, serta (3) kualifikasi pendidikan dan berbagai syarat administrasi yang lain.

Kedua, kursus keterampilan bagi pamong belajar SKB biasanya dilakukan dalam satu tahun mata anggaran baik itu dari dana block grant maupun mata anggaran lainnya. Hal-hal yang harus diperhatikan dalam pengikutsertaan kursus pamong belajar sebagai berikut. Kursus keterampilan disesuaikan dengan kebutuhan lembaga (SKB), kursus keterampilan sebaiknya memperhatikan minat dan bakat pamong belajar yang bersangkutan, kursus ketrampilan hendaknya bersifat baru, dalam arti belum ada pamong belajar yang menguasai keterampilan tersebut, kursus keterampilan merupakan peningkatan jenjang kursus yang dilakukan pada tahun sebelumnya misalnya dari tingkat terampil ke mahir, mahir ke ahli, sertifikasi, sebaiknya dihindari pengikutsertaan kursus yang hanya sekedar pemerataan, ada komitmen yang jelas dari lembaga bagi mereka yang mampu menyelesaikan pendidikan keterampilannya dan yang tidak, ada tindak lanjut bagi mereka yang telah selesai mengikuti kursus.

Ketiga, magang bagi pamong belajar SKB dilakukan bisa berupa magang keterampilan maupun manajemen program di tempat-tempat yang lebih maju 
baik, itu instansi pemerintah maupun swasta. Relevansi materi magang dan tugas lembaga sebaiknya diperhatikan.

Keempat, studi lanjut (kuliah) bagi mereka yang ingin meningkatkan pendidikannya baik itu $\mathrm{S} 1$ maupun S2 di perguruan tinggi negeri maupun swasta sebaiknya memperhatikan minat dan bakat pamong belajar, jurusan yang dipilih sesuai dengan bidang kerja, pendanaan bisa mencukupi, karir, dan jenjang kepangkatan. Kelima, belajar mandiri merupakan cara yang paling mudah bagi pamong belajar untuk meningkatkan kompetensinya adalah dengan belajar mandiri namun juga paling sulit untuk dilakukan karena berbagai faktor yang bisa mempengaruhinya antara lain minat dan bakat, tingkat kejenuhan, usia, dan volume pekerjaan. Beberapa hal perlu diperhatikan ada kegiatan membudayakan membaca, sebaiknya SKB mempunyai perpustakaan yang dilengkapi dengan berbagai buku yang menunjang tugas kepamongannya.

2. Fasilitas dan teknologi. Beberapa hal yang bisa dilakukan oleh SKB dalam meningkatkan kinerja pamong karena hambatan teknologi mengikuti perkembangan teknologi melalui media cetak maupun elektronik sehingga bisa melengkapi peralatan yang dimiliki SKB agar tidak ketinggalan jaman disesuaikan dengan anggaran yang dimiliki, memagangkan pamong belajar SKB ke lembaga yang menguasai teknologi tertentu agar bisa menguasai teknologi yang terbaru, meng-upgrade peralatan yang dipunyai jika masih memungkinkan.

3. Akses. Memberikan akses yang sebesar-besarnya kepada pamong belajar dalam mengembangkan kemampuan, aspirasi, minat, dan bakat akan membuat pamong belajar terbuka wawasannya. Dengan kebebasan mengakses informasi yang mereka peroleh, diharapkan ide-ide kreatif akan muncul dan dapat dituangkan dalam program-program yang dilaksanakan oleh SKB. Program-program SKB semakin lama akan semakin inovatif, kompetitif, dan benar-benar bisa menjadi program percontohan;

4. Reward and punishment. Kepala SKB beserta pamong belajar dan stafnya duduk bersama merumuskan berbagai aturan yang mengatur berbagai macam hal tentang bagaimana memajukan lembaga, memperhatikan beberapa hal antara lain peraturan tersebut haruslah berupa peraturan yang bulat, adil, disepakati dan dilaksanakan bersama, bersifat mengikat dan mempunyai sanksi yang jelas sesuai dengan peraturan perundang-undangan yang berlaku, dispensasi dan toleransi terhadap pelanggaran yang ada sejauh mungkin dihindari untuk menjaga kewibawaan peraturan itu sendiri, setiap prestasi baik itu besar maupun kecil sebisa mungkin diberikan reward sesuai dengan kemampuan lembaga.

5. Manajemen. Membenahi manajemen SKB baik dari segi perencanaan, pengorganisasian, pelaksanaan, pengendalian, dan penilaian pada semua elemen yang berpengaruh terhadap kinerja pamong belajar.

6. Kepemimpinan memegang peranan yang penting dalam dan berpengaruh pada peningkatan kinerja pamong belajar. Kepala SKB harus bisa meningkatkan kemampuannya dalam memberikan arahan, pembinaan, menyatukan visi dan misi seluruh elemen SKB, menyelesaikan masalah internal dan eksternal lembaga dan terus memberikan keteladanan kepada seluruh elemen SKB. Figur Kepala SKB bisa memberikan teladan bagi pamong belajar dan stafnya melalui tutur kata, perilaku, kedisipilanan dalam menyelesaikan tugas, manajemen waktu, dan manajemen keuangan.

Keempat, pengendalian merupakan salah satu fungsi yang sangat penting dalam manajemen. Pengendalian adalah pengontrolan yang merupakan suatu proses pemonitoran kegiatan organisasi untuk mengetahui apakah kinerka aktual sesuai dengan standar dan tujuan organisasional yang diharapkan. Dengan pengendalian terhadap seluruh aspek yang mempengaruhi mempengaruhi kinerja pamong belajar diharapkan hasil yang dicapai akan maksimal.

Kelima, tindak lanjut dari semua kegiatan yang berhubungan dengan peningkatan kinerja pamong sebisa mungkin direncanakan secara berkesinam-bungan sehingga ke depan pamong belajar SKB mempunyai spesifikasi tertentu dan benar-benar mahir di bidangnya. Penguasaan keterampilan yang hanya setengah-setengah akan menyebabkan inefisiensi anggaran. Oleh karena itu, penguasaan keterampilan yang hanya sekedar tahu atau sekedar menghabiskan anggaran sebaiknya dihindari sejauh mungkin.

\section{KESIMPULAN}

Pamong belajar merupakan ujung tombak pelaksanaan penyelenggaraan program percontohan dan pengendalian mutu program-program PNF yang dilaksanakan oleh SKB sehingga pamong belajar harus 
mempunyai berbagai kompetensi untuk mendukung tugas pokok dan fungsinya. Tugas pokok pamong belajar adalah melaksanakan pengembangan model program pendidikan nonformal dan informal, melaksanakan kegiatan belajar belajar dalam rangka pengembangan model dan pembuatan program PNFI dan melaksanakan penilaian dalam rangka pengendalian mutu dan dampak pelaksanaan program $\mathrm{PNFI}$.

Ada beberapa variabel yang mempengaruhi kinerja pamong belajar dalam melaksanakan tugas pokok dan fungsinya. Masing-masing variabel berpengaruh sangat besar terhadap kinerja pamong belajar. Variabel-variabel tersebut adalah kompetensi pamong belajar, fasilitas dan teknologi, akses yang menunjang tugas pokok dan fungsi pamong belajar, kepemimpinan, sistem reward dan punishment serta manajemen. Peningkatan kompetensi dilakukan dengan cara pembinaan, sekolah lanjut, magang, diklat, kursus, dan belajar mandiri. Penambahan fasilitas dan teknologi dilakukan agar sesuai dengan standar minimal fasilitas dan teknologi sehingga pamong belajar tidak menemui hambatan dalam menyelesaikan tugasnya. Untuk dukungan staf perlu adanya sinkronisasi kerja, kegiatan saling mendukung antara staf dengan pamong belajar. Adapun untuk peningkatan manajemen perlu adanya penyatuan komitmen mutu dan mempunyai prosedur kerja yang jelas.

Peningkatan kepemimpinan dengan pemberian contoh, pemeliharaan hubungan antara atasan dan bawahan sebagai dinamisator lingkungan. Peningkatan sistem dengan jalan peningkatan reward dan punishment. Peningkatan akses dengan pemberian kesempatan kepada pamong belajar untuk memperoleh informasi cepat dan akurat serta pemberian kesempatan untuk berperan serta dalam kegiatan pendidikan nonformal di lingkungan kerjanya. Upaya meningkatkan kinerja pamong belajar perlu ditindaklanjuti dengan membuat kebijakan dan kerjasama dengan pihak-pihak yang terkait agar kinerja pamong belajar dapat meningkat.

\section{DAFTAR PUSTAKA}

Hastuti, B. (2004). Pengembangan kompetensi tenaga lapangan dikmas. Tesis Program Pasca Sarjana Universitas Negeri Yogyakarta.

Nainggolan, H. (2006). Peningkatan kinerja penilik PNFI untuk pemberdayaan program PNFI di asahan. Warta Plus Edisi Juni 2006. Jakarta: Depdiknas.

Stephen, R. (2001). Perilaku organisasi konsep, kontroversi dan aplikasi. Edisi kedelapan. (terjemahan Dr. Handyana Pujaatmaka dan Drs. Benyamin Molan) Englewood Cliffs, New Jersey, 07632, Prentice-Hall , Inch. A Simon \& Schuster Company. Buku asli diterbitkan tahun 1998.

Tim Pengembang BPPNFIP Reg III. (2004). Model pelatihan pamong belajar ahli berbasis kompetensi. BP2NFIP Jawa Tengah.
Wijatmoko, A. (2004). Peran pamong belajar SKB dalam proses difusi program PADU di jawa tengah. Tesis Program Pasca Sarjana Universitas Negeri Yogyakarta.

Wartanto. (2005). Model pengelolaan kursus keterampilan berbasis life skill di sanggar kegiatan belajar. Disertasi (tidak diterbitkan). Universitas Negeri Semarang.

(2005) Peraturan Pemerintah No 19 Tahun 2005 Tentang Standar Nasional Pendidikan. Jakarta: Depdiknas.

(1999) Keputusan Menteri Negara Koordinator, Pengawasan dan Pemberdayaan Aparatur Negara No 25/Kep/MK.Waspan/6/1999 tentang Jabatan Fungsional Pamong Belajar dan Angka Kreditnya. Jakarta: Depdiknas. 